\title{
Anthrovision
}

Vaneasa Online Journal

$6.2 \mid 2018$

Visual Anthropology From Latin America

\section{The Cinematic Spell in an Island of Uncertainty}

\section{Christopher Murray}

\section{(2) OpenEdition \\ Journals}

Electronic version

URL: http://journals.openedition.org/anthrovision/3946

DOI: 10.4000/anthrovision.3946

ISSN: 2198-6754

\section{Publisher}

VANEASA - Visual Anthropology Network of European Association of Social Anthropologists

\section{Electronic reference}

Christopher Murray, "The Cinematic Spell in an Island of Uncertainty ", Anthrovision [Online] 6.2 | 2018, Online since 31 December 2018, connection on 04 September 2019. URL : http:// journals.openedition.org/anthrovision/3946 ; DOI : 10.4000/anthrovision.3946

This text was automatically generated on 4 September 2019

(c) Anthrovision 


\title{
The Cinematic Spell in an Island of Uncertainty
}

\author{
Christopher Murray
}

\section{An Uncertain Arrival}

1 I arrived in the island of Chiloé at night. A car came to take me from the ferry terminal to the hostel in Quicaví. The driver asked me why I was going there. I told him that I was a filmmaker and a student of anthropology. I was preparing a fictional film based on the famous trial that occurred in Chiloé in 1880, in which a case was brought by the Chilean state against an organisation of sorcerers called "La Recta Provincia." I was here to research and understand more than just the historical event; I wanted to know how sorcery operated and was understood by local people. I wanted to listen to their stories to help me write my script, and I would hold casting sessions to find local actors to enact the story when the film was eventually made. As Quicaví is known for having been the main base of operations of La Recta Provincia and home to most of the families prosecuted, it was the perfect place to start my research. Excited about the film project, I talked at some length. My enthusiasm contrasted with the profound silence of the driver. When I had finished, he merely smiled at me suspiciously and turned on the radio.

2 The car suddenly turned away from the lights of Quicaví ahead and onto a little road leading into a dark forest. I tried to check on my phone that this was the right direction. But there was no signal. After a few minutes, we arrived at a huge hostel, three storeys high, bordering a precipitous cliff edge and completely isolated from the village. I took my luggage and walked to the main entrance. As I moved to ring the bell, the door opened to reveal a large man in a chef's uniform, holding a knife. "Come in," he told me. I apologised for not making a reservation. "Don't worry, use any room you want. You are the only guest." The sounds of the nocturnal birds engulfed the scene.

3 I felt afraid - maybe because of all the films I had seen with openings just like this, all the fictional creatures and beings I had in my head that mediated this first encounter. I did not know whether I should take the man seriously or whether he was laughing at me. I 
felt like the classical, naïve foreigner who arrives in a world that has its own rules. That was the first, but not the last time I experienced the uncertainty that would prove fundamental to my fieldwork.

\section{A More Certain Historical Context}

4 The island of Chiloé is constantly being associated with "magic." Usually, this is a marketing strategy to attract tourists, who are encouraged to "Try the magical food of Chiloé," to "See this magical landscape," or to take "A magical journey through the national park." But "magic" here is more than an evocative word used by the tourist industry. The use of the word is connected to the particular relationship that the island has with the practice of magic and with mythological creatures. The latter exist here in the densest population in the country: a woman appears on the coast during the full moon and influences fishing activities; an elf leaves the forest, raping and impregnating women; a phantom ship ablaze with light emerges from the fog across the sea; a horrible creature, half-human and half-animal, a leg protruding from its back, stands watch over the cave of the sorcerers. Thousands of such mythological creatures comprise an integral part of the ontological landscape of Chiloé. Tracing the origins of all this cosmology is a complex task. Usually, the stories relate to notions of the conqueror and the conquered. The former are often the Spanish, who brought over a Galician mythology that then combined with native beliefs, mainly those of the Huilliches. But everything is entangled. As I was told when asking why sorcerers still attend the Catholic church despite their initiation rituals including being cleansed of their Christian baptisms by entering a waterfall: "If you want to understand Chiloé, don't try to pull things apart." It took me a while to understand that setting conceptual boundaries in the island was an impossible task.

5 The origins of sorcery in Chiloé are described in a mythical story that circulates through the island. According to this, the Spanish geographer José de Moraleda arrived one day in Tenaún, a small village on the coast of Chiloé. He presented himself as a magician initiated in a European occult tradition, and the villagers presented him to the most powerful witch on the island at the time, who was known as Chilpilla. They challenged each other to a duel to prove who had more power. Moraleda transformed himself into an animal and Chilpilla responded by sending the sea back so that all Moraleda's boats ran aground. The Spaniard was so impressed that he gave her a book of magical practices and spells. This mixing of traditional indigenous magic and European occultism was the beginning of a unique and powerful kind of sorcery. New magical practices were born and so was La Recta Provincia, which became the island's most powerful institution. The organisation spread all over the island, mostly comprising native people but structured in a European framework, for example headed by a king. The organisation became a kind of government, a guarantor of justice and health in the local communities (Marino and Osorio, 2014). The modern Chilean state, in its efforts to take control of the island, sought legal pretexts to dismantle the group; but it continued to operate as a parallel government. As witchcraft was not recognised in the modern legal code, the state accused the sorcerers of illegal association and poisoning local. A modern, state-sanctioned witchhunt began, in which more than a hundred people were arrested, most of them natives. The trial was a huge social and legal spectacle, a unique battle between witchcraft and statecraft. After a year, the trial concluded with minor sentences being handed down to 
the sorcerers (Rojas Flores, 2002). The reputation of the magical organisation, however, was so damaged by the violence of the public scrutiny that it decided to disappear.

A hundred and thirty-eight years after the trial, Chiloé is now an island well known for its touristic attractions. There is a large commercial centre surrounded by traditional houses, and a huge presence of international fishing companies all along the coast, which are accused by locals of contaminating the sea - just as the state accused the sorcerers of poisoning local people.

7 As a filmmaker, I wanted to make a fiction film about the historical trial and invite people from the community to participate. As a student of anthropology, I wanted to explore how the practice of sorcery at the core of the historical trial still works and circulates within modern Chiloé. The development of the fiction film and the anthropological research were combined in a practice-based approach, where artistic practice can be understood in itself as a means of producing knowledge (Barret and Bolt, 2007). Even though the film I was developing was not actually made during the fieldwork, certain creative practices involved in the development of the film concept are useful in the context of the research. On the one hand, the process of collecting stories to nurture the script, and, on the other, the casting sessions to find people to enact the story both provide creative devices for engaging with the community. Both involve a moment where personal narratives connect with performativity in the form of enacted storytelling. Thus, the creative process of preparing the film serves to mediate encounters with the community, creating a space of exchange that allows fluid movement between traditions rooted in the past, the contingency of present interrelationships and the uncertainty of a future, fictional project.

Before describing my encounters and experiences on the island, I briefly outline a theoretical framework to explore my fieldwork, in the context of the long development of the concepts of magic, sorcery and witchcraft in anthropological theory.

\section{Magic and Uncertainty}

9 Uncertainty is a crucial component for defining the practice of witchcraft in Chiloé. It also provides my lens to explore the vast anthropological literature concerning witchcraft and guides my use of concepts and ethnographic examples. There is no clear consensus in the literature on the use of terms such as "witchcraft," "sorcery" or "magic." Authors use the terms they deem most suitable for the context, but they may sometimes refer to similar or identical practices or beliefs. Some, such as Evans-Pritchard (1937) in relation to the practices of the Azande, have made distinctions between the terms, distinguishing "sorcery," as a skill that can be acquired, from "witchcraft," as a given, determinate condition. In Chiloé, the terms "sorcery" and "magic" are usually related to acts of evil. But the definitions shift in everyday usage: during my fieldwork, I noticed how Huilliches would often accuse the Spanish and Chilean invaders of categorising their rituals as sorcery as a means of attacking them; yet, sometimes they too refer to themselves - with pride - as sorcerers.

10 A relationship between magic and uncertainty has been articulated since the first anthropological explorations of the topic, around the beginnings of the discipline. James Frazer (1900) sets up a close relationship between science and magic, as two practices that aim to control nature by invoking immutable and certain chains of events. For 
Frazer, magic operates like a pseudo-science, giving certainty to nature through an overall structure, but based on a mistaken way of thinking. Malinowski (1954) adopted a more pragmatic approach, arguing that magic was used by the Trobrianders in moments of anxiety, confronted by the uncertainty of calamities or exceptional conditions which exceeded the realm of their practical knowledge. Meanwhile, in his influential ethnography on the Azande, Evans-Pritchard (1937) describes witchcraft as a system with its own rationality, a coherent and certain system of beliefs that fully explain the causality of events.

11 In the postcolonial context, we see the exploration of magic, witchcraft or sorcery taking place in the context of the uncertainty of modernity and global capitalism. Magical practices and beliefs are seen as leaking through the fractures in ideas about social and economic progress. The proliferation of these practices indicates that witchcraft is reinventing itself as a contemporary tool to confront the unstable sociopolitical and economic context. Detailed ethnographic evidence has been gleaned for example on "occult economies" in post-colonial South Africa (Comaroff and Comaroff, 1999), on the presence of spirits in modern infrastructure in Thailand (Johnson, 2013), and on the linkage between political power in the modern state and that of Amerindian shamanism (Whitehead and Wright, 2004). The supposed "disenchantment of the world" (Weber, 1969) has proven only another myth of modern thinking - some have argued, like "modernity" itself (Latour and Porter, 1993; Josephson, 2017). Maybe there was never a "disenchantment" or a "re-enchantment," only the arrival of modernity as a "new enchantment," invoking new spells and incantations as expressed through politics, economics or even science.

12 Even in this more contemporary perspective, where "occult" practices become a tool to support critical analyses of modernity, witchcraft still exists in relation to a context of uncertainty: namely, the uncertain conditions that global modernity brings to local communities, mainly through its economic and political expressions.

13 The relationship between uncertainty and witchcraft can also be framed in the context of colonial projects worldwide. In Chiloé, the existence of an organisation of sorcerers contemporaneously with the Spanish conquerors and then the Chilean state is usually explained as an expression of cultural resistance. In Sierra Leone, between 1860 and 1900 (around the same time as the trial of La Recta Provincia), the colonial government was making efforts to eliminate the so-called "human-leopard societies," secret groups that practice killings against people pretending to be leopards and who were denounced for destabilising the social order. Jackson (2013) argues that, though this was part of the culture of Sierra Leone, the uncertain context of colonialism gave these practices a new, rebellious impetus based in the form of resistance and revenge.

14 A similar account is given by Neil Whitehead (2002) in his extended work with kanaima "dark shamans" - in the Guyanas. This group practise what Whitehead calls "assault sorcery," extreme performative killings which involve precise mutilation rituals. For Whitehead, the violence of the kanaima mimics the violence of economic and political development in the region, which is aggressively and effectively imposed. As a reaction to this, the kanaima take a "hypertraditionalist" position to affirm Amerindian autonomy. From their beginnings in the nineteenth century, the practices of the kanaima appeared as a "defensive magico-military technique to ward off the new and overwhelming gun violence and slave raiding" (Whitehead, 2002: 250). During the rule of La Recta Provincia in the island of Chiloé, magical tribunals were organised which sentenced to death encomenderos - 
Spanish slave owners or local authorities accused of abusing local communities. The dark sorcerers in Guyana, the human-leopard creatures in Sierra Leone and La Recta Provincia in Chiloé all enact organised violence in reaction to the similarly violent expressions of the colonial project within local contexts.

Magic becomes a system for coherently explaining the uncertainties of daily life in societies like the Azande or the Trobriand, an emerging force of resistance in the violent contexts of specific sociopolitical crisis, or a response to the fractures of modern democracies and global capitalism. In all of these cases, witchcraft mutates (or shapeshifts) to attack the uncertainty that circulates in communities. As Parés and SansiRoca (2011) argue, it is the ambiguity of the occult - of secrecy, of liminality, of the practice and nature of witchcraft - that gives it the plasticity to shape itself depending on the context. Paraphrasing the famous line in Evans-Pritchard (1937: 513), quoted also by the Comaroffs (1999: 279) and Max Gluckman (1963: 141), they write: "When old spells do not work, new elements, new words, new techniques can always be summoned" (2011: 7). That is, new challenges demand new magic.

But the concept of uncertainty can be pushed further in the analysis of witchcraft. The work for example of Morten Axel Pedersen (2011) in Mongolia, or of Neil Bubandt (2014) on the Indonesian island of Buli suggests witchcraft need have no specific social function, role or discourse. In the case of Mongolia specifically, Pedersen explores a society submerged in uncertainty due to the fall of socialism and the new openness to the flux of capitalism. Amongst such instability, shamanic and occult forces circulate and possess people - but without any shamans to control them because of the abolition of the shamanic institution during the Soviet period. The situation of people affected not only by uncontrollable shamanic spirits but also the uncontrollable forces of the free market create conditions of total uncertainty. The ethnographic encounter described by Pedersen is an ambiguous connection: one never knows where one stands or with whom one is talking. In the case of the Buli in Indonesia, Bubandt describes the "guas," sorcerers who exercise a similar kind of "assault sorcery" to that practised in Guyana - but without any clear social or political function within their community. They exist solely to attack but no-one knows know when they will do so, or why. The anguish that this uncertainty produces pushes people on Buli to embrace expressions of modernity like the nationstate, capitalism and even Christianity, as a way of dealing with the ambiguous and unexplainable existence of the guas.

17 These examples offer a clear inversion of the argument already mentioned, as propounded by anthropologists like the Comaroffs $(1993,1999)$ or Geschiere (1997), that witchcraft and "occult economies" offer a way out of the uncertainty of modernity and global capitalism within local contexts. In the case of the Buli, modernity instead becomes a way to deal with the uncertainty of sorcery. The circulation of uncertainty in these different theoretical approaches and ethnographic encounters help me establish comparisons and inform my own fieldwork experience.

\section{Uncertain Neighbours}

18 One morning while I was having breakfast in the hostel, the cleaning lady ceased her sweeping to come to talk to me. She was around 50 years old and was wearing a large scarf. She asked me if I was the person collecting stories about witchcraft for a film. I confirmed this and she took a seat. She told me that her mother, Juana, who was now 100 
years old, had had ten children but seven of them had been killed when they were babies by a neighbour who was a sorcerer. She herself was almost killed: one evening when she was a child, she felt a sudden blockage in her throat. The family called an indigenous healer - a "machi" - to help her. When he arrived, seeing the situation he took a kitchen knife and performed an emergency tracheotomy on the girl, extracting a ball of hair.

19 I was shocked. While telling her story the cleaning lady took off her scarf to show me the lesion on her neck. It was a huge mark which, she said, reminded her always of that evening. When she had finished her story, I went with her to ask her elderly mother about this ordeal. The old lady told me that she thought the neighbour made the attacks because he was jealous of her happy family. When I asked whether anyone from the family had confronted the man, the answer was no. They were almost sure he was the killer, she said; but then again, you never know for sure. They had lived as neighbours for years, until the man died. The idea of living a few metres away from your children's killer, or possible killer, stayed in my mind. This sorcery was not merely one night of trickery, but the on-going slaughter of a family's babies and children.

These same types of serious accusations between neighbours circulated during the years prior to the 1880 trial of La Recta Provincia. The modern Chilean state knew the group was active and influential in local communities. It provided a kind of magical court, resolving conflicts between neighbours and imposing justice through witchcraft. Despite plenty of testimonies, the state and the modern tribunals had no legal weapon to confront the group. In the Penal Code of 1875, the pride of the Republic of Chile, there is no trace of the idea of sorcery. The state finally decided to use the notions of "illegal association" and "poisoning" to bring the sorcerers to trial. Using this strategy, the "modern tribunal" confronted the "magical tribunal." Sorcery falling outside the legal framework of the trial, there could be no resolution affirming that someone was indeed a sorcerer. The certainty of the legal system was incompatible with the uncertainty of witchcraft, even in situations where, for all affected parties, sorcerers were responsible for the actions in question. Stories of sorcery are not confined to the past. In 2007, 15 cases of witchcraft and black magic were presented to the Public Ministry. One of these concerned someone who accused a neighbour of placing a cloth containing dust from a graveyard in his garden, so as to bewitch him. The prosecutor said to the press: “...these acts are not considered crimes." But the relationship between modern courts and witchcraft is not always so bounded. In Cameroon, the court can address accusations of witchcraft using professionals with mystical expertise, officially recognising the existence of witchcraft (Siegel, 2006).

21 Accusations made between neighbours are not only mediated by "magical" or "secular" tribunals, but also by private conversations and everyday actions. Early in my fieldwork, most people referred to sorcerers as something that existed in the past. One woman said during the casting sessions: "You want to find sorcerers? Not anymore - now we have to go to the hospital." In some cases, people made jokes: "Be careful of going to visit this woman; she can enchant you, take all of your money." Or they were deliberately playful, using the traditional, ambiguous proverb: "I don't believe in witches, but they do exist." Sometimes this ambiguous context made me feel quite confused; I would try to ask for a specific name, but no one wanted to talk about a specific person. Asking for a particular name was something controversial, like crossing an impenetrable frontier. At least, it seemed this way with most people. But one person broke this apparent local rule. 

language. The language became practically extinct after Spanish colonisation but, for historical accuracy, I wanted it to play a role in the dialogues in the film. I found a teacher of native languages at the school, who was also a pastor at a Pentecostal church. A few days later he invited me to a Pentecostal gathering, and I asked him if I could film. During the event, he started to speak against the sorcerers. Suddenly, the camera switched itself off; I found that all the footage was erased. After the gathering, when I told him what had happened, he accused someone he thought was a sorcerer who had infiltrated the Pentecostal group. He indicated someone sitting in the first row. In contrast to others in Quicaví, he did not hesitate to provide specific names: "God is with me, so I am not afraid of these people." His words were full of anger and reflected a clear tension between the Pentecostal Church and the practice of witchoraft.

From the pastor's point of view, witchcraft existed as part of a pact with the devil. He had experienced it in his own family: a neighbour once offered to help clean the church and afterwards started to become more and more involved with the church community, even joining the choir. Every service, she sat with the choir directly behind the pastor's wife who started to feel ill. After she had a vision in a dream, the pastor's wife realised that the woman was a witch who was infiltrating the church. She was accused in front of the entire congregation, just as in a classical inquisition process like the Salem trials. The accused did not say a word and left the church forever. She still lives next door. The pastor revealed a long list of neighbours suspected of witchcraft, some of them people I knew, which made me feel uncomfortable about my relationships with them - I began to wonder who these people really were.

When I brought up these stories with other villagers, they said that the pastor used this strategy of accusation as a way of attracting more people to the church. He had even accused the other Pentecostal church in the village of being a front for the sorcerers. This particular accusation resembles one made during the nineteenth century against sorcerers in Chiloé, who were supposedly working as Catholic priests in a strategy of dissimulation.

Besides the public naming, the ambiguous stories and rumours, even the funny anecdotes about various neighbours that circulated by word of mouth were all ways of accusing yet in a more uncertain manner. For example, when the owner of a local store made a lot of money from one day to the next this was explained by his having made a pact with " $\mathrm{El}$ Caleuche" - a sorcerers' ship. This connection between wealth and witchcraft resembles some similar supernatural accusations in South Africa, about zombies being used as a working force, as an explanation for the lack of labour and the unexplainable enrichment of some people (Comaroff and Comaroff, 1999).

In contrast to the serious, certain accusations of the pastor, other local people tell these stories more ambiguously: they develop very seriously but are always accompanied by a laugh in the end. Such ambiguous accusations also act and influence social relationships in the community. For example, one night the local store owner and his family came to the hostel where I was staying, asking for drinks and food. It was impossible not to see him in the context of the images and stories I had collected about him. When he asked me what I was doing on the island, I felt uncomfortable explaining that I was developing a film about witchcraft. He did not say a word, while the rest of the family laughed. Days later, some villagers told me more severe accusation related to this family, namely that they participated in illegal salmon smuggling. Instead of a pact with a sorcerers' ship, 
they had reached an agreement with some of the workers in the big salmon farms off the coast. Was the pact with El Caleuche being used as a metaphor or code to refer to the smuggling - or was this a real belief?

Stories like this circulated all the time, creating an uncertain web of relationships between neighbours. Accusations, through stories, travelled like narrative spells between houses, affecting and conditioning social relationships.

\section{Uncertain Animals}

One evening I was writing up some field notes and trying to connect them with ideas for the film script - attempting to interweave local stories with historical events. My desk looked out over the sea: as the hostel was completely empty, for very little money I had been able to choose the biggest room with the most beautiful view, which I hoped might inspire me. While I was writing, something caught my attention: a small object in the sky, a dot at first, but bigger and bigger. I realised too late that it was headed straight for my window - a large, black bird smashed into the pane right in front of me. I jumped up, scared, and hid behind the bed. I watched as the bird struck the glass twice more before disappearing. Later, while I was eating, I told Bruno, the chef, of my experience. He said: "Maybe the sorcerers came to say hi." Others I asked told me that birds were often attracted by their own reflections in window panes. Was this bird a sorcerer in the body of an animal or just an animal attracted by its reflection? Or when the sorcerer becomes a bird, perhaps he becomes also enamoured with his own image?

Shape-shifting is a crucial capacity of the sorcerers in Chiloé. Most of the stories I had heard referred to transformation into dogs or birds, although there were also sorcerers who had turned into pigs, cows, horses and even cats, as Juan Martinez told me during one of the casting sessions. Juan came to the sessions very enthusiastic, referring to himself as someone who had often been affected by witchcraft - perhaps he thought this would secure him the role. One of his experiences involved a cat that got among his chickens. He went to defend his animals but was frightened when he saw that the cat did not have a tail. He tried to kill it with an axe, eventually dealing it a heavy blow to the spine with the axe handle. The cat seemed to be dying and he left it on the road; a few minutes later, it had disappeared. The next day, he heard an old neighbour was suffering from terrible back pain. The man called Juan over to his house and asked for his forgiveness. A few days later, he died. Juan affirms that, ever since, he has wondered whether he hit a cat that night, or his old neighbour.

This is a common structure in stories of sorcery in Chiloé: an animal gets hurt one day, and the next a neighbour appears to be suffering corresponding effects. What is interesting is that all these stories establish a doubt; there is no certainty that the neighbour really was the animal. There is a whole night between the elements of the story, a hiatus in the sequence of events that precludes the affirmation of a direct cause and effect. Alfred Gell (1988) describes this lack of direct causality as a property of magic that distinguishes it from other technical strategies. It is an ontological uncertainty: one never knows if one is dealing with an animal or a human.

31 After I had listened to the stories and experienced for myself the incident with the bird, my relationship with the environment shifted in two ways. First, all the local animals started to seem uncanny. The possibility that someone in animal form was being 
observing me, put me in a strange state of vigilance. Maybe it was just paranoia; or maybe I was experiencing the configuration of a new ontological environment where the boundaries between beings were not as clear as I was accustomed to. Second, when I went back to the script, I found I was approaching the characters in a different way. Classically, characters are bounded entities, clearly described and identifiable in the narrative - but this did not seem to fairly reflect the kind of world I was experiencing in my fieldwork.

\section{Uncertain Roads}

In Chiloé, tourism and mythological creatures frequently cross paths. In Quicaví, for example, a sign that hangs on a tree outside a house reads "Mythological Circuits." Here I meet Koky, the neighbour behind the construction of this touristic and mythological path who also guided the walks. He thinks sorcerers used to conduct their initiation rituals here. The route features handmade wooden sculptures at intervals, representing the ritual acts and the mythological creatures that are involved. Koky thinks that one of the many caves where the organisation used to meet is also here. But nothing is completely certain - Koky is clear about that. A lot of people in the village do not dare to visit the cave, frightened by the sounds of the human-animal creatures who protect it, and by the smell of their excrement ("It smells like sulphur," the nurse told me at the health centre in Quicaví, while administering medication to an elderly couple). Koky's brother does not dare to follow the path alone, although he helped to make it. "There is a strange energy that keeps people away," Koky told me. He said some tourists had visited a camping spot nearby. But after taking the walk, they left without providing any explanation.

There is a common story told in Chiloé that relates to pathways and uncertainty. One version I heard began with two players having a fight during an amateur football match in a rural area. After the match, one of them left to go home but suddenly found he had lost his way in the forest. After hours of walking, he fainted. When dawn arrived, he realised he had been only a few metres from his home the whole time. He connected this experience to the argument he had had at the football match. His antagonist was the relative of a sorcerer - who was probably taking his revenge by making him lose his way. The man told me no alcohol had been involved to explain his getting lost; it was clearly a magical revenge. This clarification evoked the ambiguous uses of the stories that proliferate throughout Chiloé. As in the pact with the sorcerers' ship as a reference to illegal smuggling, or the elf in the forest who rapes women as a way of talking about undesired pregnancy, in the getting lost story, the narrator makes clear that there is no metaphor or justification, only a possible trick of the old sorcerers.

The same story is heard over and over, with different experiences placed in the same narrative structure. The capacity of the sorcerers to make people lose their way, reshaping the landscape by altering perception, again works to create uncertainty. Like the sorcerers in Buli, the sorcerers here act as "master(s) of deception, playing tricks on human consciousness, knowledge, memory, and senses" (Bubandt, 2014, p. 8).

The work of the sorcerers almost amounted to the opposite of that performed by the highway workers I often saw while driving around the island, working to increase connectivity between places: on the contrary, the sorcerers were making uncertain pathways to disorient people. This practice of disorientation is also evidenced in the documents relating to the historical trial of 1880 . These describe how La Recta Provincia would refer to places around the island using code names based on cities in other Spanish 
colonies, as part of their strategy of dissimulation and distraction. The city of Achao, for example, became "Buenos Aires," Queilen became "España," Quicaví became "Lima," and so on. The new map of the island, describing the expanded power of the sorcerers, overlapped with the official map used by the modern state: the code names were a way of disorienting the Republic - just as I was becoming more and more lost during my research.

\section{An Uncertain Organisation}

To find local, native actors for the film, I gained access to an important meeting of indigenous representatives from different communities. These were convened with governmental authorities to discuss the new Constitution and its relation with indigenous people. At the end of the meeting I was given time to present my project. I told the delegates that I was preparing a film about the 1880 trial against La Recta Provincia, and that I wanted to recreate this crucial historical event using local people as actors. I emphasised that I wanted to delve behind the official documents, in which the organisation was treated like a group of fraudsters. Rather, I aimed to explore how the operations of the state represented a strategy to gain power over local and native communities. After my short but enthusiastic presentation, an uncomfortable silence reigned. Slowly, hands started to be raised. The message was clear: you cannot make the film without asking for authorisation. It seemed that gaining permission from local island dwellers, as I had been doing throughout the process, might not have been enough. Perhaps they were referring to community leaders I was not aware of, or even the local state authorities. I was wrong: I needed to seek authorisation from La Recta Provincia itself. The two hundred people in the room seemed overwhelmingly to support this warning.

Until that moment, La Recta Provincia had been for me only a defunct, now mythical organisation connected with historical events. But at the meeting, I realised that it was something alive, active even now; more than that, the future of my project seemed to be in its hands. As a filmmaker I had discussed my work with producers, distributors and sales agents, but never with an organisation of sorcerers.

After the meeting I approached some of those who had spoken to try to find out more information. If La Recta Provincia was still active, how could I contact the sorcerers? Where were they? Who were they? But all the answers were ambiguous: "Maybe I can ask someone who knows someone that can give you some information"; "You cannot contact them, but I think they are going to contact you"; "They say they usually meet somewhere in the south of the island." I was now in the hands of an organisation with no face and no place. I began to feel uncomfortable. "If you don't get authorisation, you could end up like the owner of a private forestry company who once wanted to use our woods: now they're six feet under. We know how to deal with nature"; "You can make your film, but if you do not seek authorisation from the organisation it will never see the light of day." I did not know whether these warnings were meant to be taken literally or a means of showing me, a filmmaker from the outside, where the power lay. They rendered my position one of uncertainty; any claims I might try to make in terms of my authority over the film were placed under the sway of an uncertain organisation. near Ancud, in the north of the island. But the people there sent me to Queilen, in the 
south, and from there I was sent to Castro, in the centre. I felt lost like the people in the stories, disoriented by the sorcerers. Since there seemed no clear way to prove the organisation's existence, I started to doubt it. Then, two encounters seemed to confirm its agency in the native communities.

Through the casting process, I met the chief (or "Cacique") of the organisation of indigenous communities, the main authority acting on behalf of the native peoples on the island. He had previously participated in documentaries and I was surprised by his charisma in front of the camera. I thought he might be able to portray La Recta Provincia's king in the film, and I asked him if we could meet. We had two meetings in a rural area called Huillinco: one to explain the project and a second to record a test on camera with the script. During the second meeting, he told me that he thought it was a great film project but did not want to participate. This took me by surprise. He said he was afraid to be in the film. If he portrayed someone from La Recta Provincia, the organisation might take revenge - not directly on him, but on his family, as was the sorcerers' modus operandi. It seemed the organisation was not merely a player in a historical event, but an actor with continued influence.

The second crucial encounter came after several days spent exploring and following up all my contacts for information about the sorcerers. I travelled all along the island until suddenly I was finally able to speak with someone on the telephone who never said explicitly that he was part of the organisation, but who suggested he was really close. We arranged to meet in Castro, the island's main city. I wanted to record the conversation, but he did not agree to this. I was going to explain my plans - but he already knew about them. Through meetings, phone calls and WhatsApp groups, it seemed that people associated with La Recta Provincia had been made aware that someone from outside was conducting casting sessions to produce a film about the organisation. I told him about my script, based on the trial of 1880 and adopting the perspective of those indigenous people who were imprisoned. I also told him that I was inviting people from Huilliche communities to participate as actors. But he told me they were not interested in participating - maybe in a documentary, which might present the truth, but not in a fiction film. He was clear. Even if I persisted in attempting to make the film, no one from the community would participate. I initially thought this was his opinion. But it seemed this was a decision that had already been reached in discussion with other people of this organisation. People who had attended the casting sessions I had already held in some of the villages had been contacted by the organisation and required to step away from the project. People had even been reprimanded for taking their children to the casting sessions. As in my encounter with the main Cacique, I realised that the organisation wielded considerable influence in the communities - and that something about the film had given rise to resistance.

Our conversation confirmed that La Recta Provincia retained a capacity to expel forces that came to the island with the intention of exploiting it for profit. He associated La Recta Provincia with catastrophes experienced by the salmon fishing companies in the past, and with the absence of Pentecostal churches in some sectors of the island. He also alluded to possible future actions against the bridge being planned by the state to connect the island to the mainland.

43 My contact remarked that La Recta Provincia was a strong organisation, no mere collection of isolated sorcerers. He told me about some sorcerers who had decided to disassociate from the organisation and work alone, asking for money to kill people - 
magical hitmen. But the ritual process for killing someone is so powerful that it can only be conducted by a group of sorcerers, who might distribute the magical energy amongst themselves; when the sorcerer works alone, he dies along with the victim.

I asked him again: "Are you part of this organisation?" He did not answer directly. I insisted, asking whether he knew people from the organisation. He answered, "maybe some." As a security strategy, it seemed, even those inside the organisation did not know each other. Even faced with someone connected and possessing plenty of information, the organisation still seemed shrouded in uncertainty.

After this encounter, it had become clear that resistance was an important element of discourse and practice surrounding the role of La Recta Provincia in the island: resistance to foreign-owned fishing and forestry companies, resistance to foreign beliefs such as Pentecostalism, resistance to the infrastructure of the state in the form of the bridge. But why was there resistance to my fiction film? If the trial was historically documented, what was the problem with representing it in a film? What threatening force did my film represent?

\section{An Island of Uncertainty}

As I have described, throughout my fieldwork - the casting sessions, the stories, the personal encounters, the tricks and attacks of the sorcerers - the landscape of the island always seemed shaped by uncertainty. All these experiences brought into being a world where the boundaries between entities were ambiguous, at least to the outsider. The island's animals, the local people and pathways, La Recta Provincia itself all appeared impossible to fix, contain or define with certainty. At first I encountered this uncertainty as something involuntary, but as the discourse of resistance revealed itself I came to understand it as a performed, intentional strategy - a strategy of isolating the other from the means to navigate this world or at least of submerging them within relations of power.

The produced landscape of uncertainty emerges and contrasts with the processes of control that modernity has brought to the island. To develop this idea, I will provide two interesting examples from my fieldwork. The first is related to the processes of capitalism that work through the fishing companies, in which animals are transformed from living beings into commodities. I was permitted access to one of the salmon plants, where I saw how the fish are measured, disinfected, classified, re-distributed through tubes and then taken out to sea, continuing to grow in cages. While I was filming, the plant supervisor asked me about my project. As we talked of sorcerers and shape-shifting, before our eyes the industrial infrastructure was containing these animals, limiting their openness to the ambiguous world "out there"; from another perspective, the fish were being "shapeshifted" via the magical processes of industrial technology.

I found something captivating in this tension between the industrial search for certainty and the production of uncertainty practised in sorcery. At night on the island, one might catch sight of some bright lights out on the sea, sometimes in motion, sometimes fixed. A moving light is probably a sorcerer travelling from one island to the next, wearing their " macuñ" - a vest made of human flesh which radiates light due to the human oil taken from the cemetery's dead bodies. Almost everyone in Chiloé will have seen such a light. A big, fixed source of light, however, is certainly the artificial lighting the salmon 
companies used to accelerate the growth of the fish. The two kinds of light appear together: the artificial light, an expression of modernity, appears in tension with the light of the sorcerers. An old woman who attended one of the casting sessions expressed this idea. "When artificial light started to illuminate the island's pathways, the sorcerers started to disappear." Perhaps it is not surprising that the sorcerers, as figures of uncertainty, were uncomfortable with the certainty of clearly illuminated routes.

Another expression of modernity is found in the huge bridge which the state has been promising for decades and will connect the island with the mainland. While some see the project as a way of bringing progress to the area and facilitating movement around the country, others see it as a concrete manifestation of the efficiency demanded by the mining, forestry and fishing industries to extract natural resources. At present, the island can only be accessed by private transfer via the "Chacao Channel" and passage is dependent on the weather. Thus, the island can only be reached across a threshold of sea, fog and rain. The bridge project is a modern dream, promising certainty by improving the connectivity of the island. From the perspective of its opponents, it will increase the control that is exerted over the territory by industrial processes. This is what lies behind the sorcerers' threats to act violently against the bridge.

The construction of the bridge could also be read as a loss of their definition as an island, not only as a geographical territory but also as a place where insularity reaffirms local identity. All the sorcerers' strategies of producing uncertainty, I argue, are related to creating a world where the other is always relegated to the outside, or is at least required to follow an ambiguous path through a world with its own rules. The geographical feature of being an island is in every aspect entangled with local identity and autonomy.

51 In this context, I sought to understand what was producing resistance to the idea of making the film. What prompted the emergence of the barrier to the native communities' acting in it? What was the threat posed? Up to now, I have explored how magical procedures act on the outsider by producing uncertainty as a strategy of maintaining power. But how does the film act in return? Might the film also be considered a kind of sorcery that threatens magical practice?

\section{The Cinematic Spell}

There are certain parallels between filmmaking and sorcery which mediated my relationships with the islanders. I will look at one aspect of this, for which I will use the term "sympathetic magic," developed by James Frazer (1900) and then revisited by Taussig (1993), which seeks to encapsulate the parallels between film as a mimetic practice and certain magical procedures based on producing copies of an original. For Frazer, sympathetic magic is a kind of magic based on imitation - by affecting the copy, you affect the original. But what is potentially more interesting in relation to our own exploration is the Law of Contact, which establishes that when the copy or secondary object comes into contact with the original, it can still affect it. A clear example of this is voodoo practice. The creation of a fiction film incorporating a cast of locals could be read as a sympathetic practice in this sense. By using an element of the other (the body), one creates a copy that is not exactly the same but has power over and acts on the original. On one occasion where I tried to explain the film to local people, someone queried: "And what control are we going to have over the film?" The question is pertinent and complex. Even where communities and inhabitants are integrated in the creative process, a film is 
still designed by an author. The final creation not only comprises a story, but yields fictional beings that keep circulating throughout different territories, cultures and communities, even within the context where the film was conceived. The existence of these fictional beings alters the balance, or the ontological configuration, of the place. It thus became clear to me that it was important for some local people to have some kind of influence over the creation of the film.

Recall the scene with which I opened this article, my apprehension at approaching a village and a people I did not know. It was not these things in themselves that scared me; rather, the relationship was mediated by the fictional beings, the narrative spells of a thousand films, which I already had in my head. Is a film a device of uncertainty or certainty? The answer may depend on one's perspective. Certainly, from the perspective of the locals, it seems that entering the process of creating a film, more than a ludic experience of self-expression, is to enter uncertain territory, a new, fictional island, where new spells are enacted, new beings are brought into existence. Most importantly, uncertainty as a their strategy of resistance is redistributed, away from their grasp. We could say that by creating a linear story one also creates a concrete narrative pathway, which might work against the uncertain pathways of the island. In other words, the concreteness of the island's characters, who operate through the shadows, is undermined in the cinematic light.

In conclusion, I argue that sorcery in this context is a practice based on producing uncertainty as a means of resistance to constant threats from external forces. It is clear that the discourse of sorcery has changed since the times of the trial of La Recta Provincia in the nineteenth century. Then, sorcery was about dealing with conflicts in communities, providing justice and health through magic - in other words, providing certainty in moments of uncertainty. But now, the provision of justice and health is in the hands of modern institutions. After the trial, La Recta Provincia withdrew into secret, uncertain spaces. Since then, for Chilotes, although the organisation still exists and acts, the sorcerers are no longer a motor of certainty; rather, they are an uncertain, occult organisation. But the sorcerers have no monopoly on witchcraft and magical practices. Neither are such practices distributed by a central entity like the state; rather, they are in constant movement. They circulate around the island's pathways and geographical landscape, the relationships between neighbours, the local animals, the fog, Koky's touristic walks, the caves, the people's humour and stories. They circulate without a concrete body or responsible. The practices of magic thus shape and reaffirm the ambiguous identity of the island of Chiloé.

The core of my methodology throughout the project was the creative collaborative process of developing a fiction film as a device to promote ethnographic encounters on the island. I was not just collecting stories in the abstract, but collecting for a script. I was meeting people not just to talk, but to invite them to casting sessions. I was not capturing images and sounds only for data analysis, but to work out how to capture visually and sonically the uncertain landscape of the island in my hypothetical film. Controversially, I was trying to make visible what was maintained - often intentionally - as invisible, and to make audible what was often maintained as silent. Their refusal to be recorded made it clear that capturing people in images and sounds seemed a violent practice to some, an attempt to make concrete and certain something that operates intentionally in a less tangible dimension. 

impossible to mimic uncertainty in the weak certainty of the orthogonal images that limit film. How could my film mimic the rich and complex ambiguity of the island? Alternatively, the project's own magical potency posed a threat, rendering uncertain the island's very uncertainty, like a spell of uncertainty acting back. The "magical authorities" distrusted the project either because its uncertainty was a threat or because its certainty was insufficient. Maybe the only way out would be to generate a film and a dynamic creative space that works in harmony with the capacity of sorcerers to shapeshift, oscillating between the paths of certainty and uncertainty.

In that oscillating movement, the main challenge is in the process of creating in and with a community. If this fiction film is ever made, the question will be how to shape a space of mutual confidence, to dissolve both the threat and the resistance posed to it - or at least to make this tension mutually acceptable. Finding an answer to this question might promote the emergence of a collaborative cinematic spell, a film able to circulate around the pathways of this island of uncertainty.

\section{BIBLIOGRAPHY}

Barrett, E. and B. Bolt. 2007. Practice as Research: Approaches to cCreative Arts Enquiry. London: I.B. Tauris.

Bubandt, N. 2014. The Empty Seashell. 1st ed. Ithaca and London: Cornell University Press.

Comaroff, J. and J. Comaroff. 1993. Modernity and its Malcontents. 1st ed. Chicago: The University of Chicago Press.

Comaroff, J. and J. Comaroff. 1999. Occult Economies and the Violence of Abstraction: Notes From the South African Postcolony. American Ethnologist 26(2): 279-303.

Evans-Pritchard, E. 1937. Witchcraft, Oracles, and Magic Among the Azande. Oxford: Clarendon Press.

Frazer, J. 1900. The golden bough: A study in magic and religion. 2nd ed. London: The Macmillan Co.

Gell, A. 1988. Technology and Magic. Anthropology Today 4(2), 6-9.

Geschiere, P. 1997. The Modernity of Witchcraft. Charlottesville [Va.]: University of Virginia Press.

Gluckman, M. 1963. The Magic of Despair. In Order and Rebellion in Tribal Africa: Collected Essays with an Autobiographical Introduction. M. Gluchman. Pp. 137-145. London: Routledge.

Jackson, M. 2013. Lifeworlds: Essays in Existential Anthropology. Chicago: University of Chicago Press

Johnson, A. 2013. Progress and its Ruins: Ghosts, Migrants, and the Uncanny in Thailand. Cultural Anthropology 28(2): 299-319. http://dx.doi.org/10.1111/cuan.12005 (accessed 2July 2019)

Josephson, J. 2017. The Myth of Disenchantment: Magic, Modernity and the Birth of the Human Sciences. Chicago and London: The University of Chicago Press. 
Latour, B. and Porter, C. 1993. We Have Never Been Modern. 1st ed. Cambridge: Harvard University Press.

Malinowski, B. 1954. Magic, Science and Religion: And other Essays. Garden City, N.Y: Doubleday. Marino, M. and Osorio, C. 2014. Juicio a los brujos de Chiloé. 2nd ed. Santiago: Ediciones Tácitas. Parés, L. and Sansi-Roca, R. 2011. Sorcery in the Black Atlantic. Chicago: University of Chicago Press. Pedersen, M. 2011. Not Quite Shamans. 1st ed. Ithaca: Cornell University Press.

Rojas Flores, G. 2002. Reyes sobre la Tierra. 1st ed. Santiago de Chile: Editorial Biblioteca Americana.

Siegel, J. 2006. Naming the Witch. Stanford (Calif.): Stanford University Press.

Taussig, M. 1993. Mimesis and Alterity: A Particular History of the Senses. New York and London: Routledge, Chapman and Hall, Inc.

Weber, M. 1969. Science as a Vocation. In From Max Weber: Essays in Sociology H. H. Gerth and C. Wright Mills, trans. And eds. Pp. 129-156. New York: Oxford University Press.

Whitehead, N. 2002. Dark Shamans: Kanaima and the Poetics of Violent Death. Durham and London: Duke University Press.

Whitehead, N. and R. Wright. 2004. In darkness and secrecy. Durham and London: Duke University Press.

\section{ABSTRACTS}

I arrived in the island of Chiloe with the idea of making a fictional film about the 1880 Chilean State trial against a powerful organisation of sorcerers. Based on the experiences and encounters that emerged from my attempt to develop the film through a collaborative approach, I argue that witchcraft on the island works not simply as an old myth but as a contemporary practice of resistance. Knowledge, stories, silences about witchcraft counteract and produce multiple levels of uncertainty regarding forces external to the island and to peoples' lives as a way of reaffirming local identity. Lastly, I explore how the very idea of the film about the trial, and the uncertainty provoked by the nature of fictional stories, can be read as a kind of witchcraft, or "cinematic spell", that incites the resistance of the local community.

Je suis arrivé sur l'île de Chiloé avec l'idée de faire un film de fiction sur le procès de l'Etat chilien de 1880 contre une puissante organisation de sorciers. En me servant des expériences et des rencontres qui ont résulté de ma volonté de développer le film par une approche collaborative, je soutiens que la sorcellerie sur l'île ne fonctionne pas simplement comme un vieux mythe mais comme une pratique contemporaine de la résistance. Les connaissances, les histoires, les silences sur la sorcellerie contrecarrent et produisent de multiples niveaux d'incertitude concernant les forces extérieures à l'île et à la vie des peuples comme moyen de réaffirmer l'identité locale. Enfin, j'explore la manière dont l'idée même du film sur le procès, et l'incertitude provoquée par la nature des histoires fictives, peuvent être lues comme une sorte de sorcellerie, ou "sort cinématographique", qui incite la résistance de la communauté locale.

Llegué a la isla de Chiloé con la idea de hacer una película de ficción sobre el juicio del Estado Chileno en contra de una poderosa organización de hechiceros. Al basarme en las experiencias y encuentros que emergieron tras mi intento por desarrollar el proyecto a través de un enfoque colaborativo, argumento que la brujería en la isla funciona no sólo como un mito antiguo sino 
también como una forma contemporánea de resistencia. El conocimiento, los relatos y los silencios sobre la hechicería frenan y producen múltiples niveles de incertidumbre sobre las fuerzas externas a la isla y las vidas de sus habitantes lo que a su vez reafirma la identidad local. Finalmente, exploro cómo la mera idea de la película sobre el juicio, y la incertidumbre provocada por la naturaleza de los relatos ficticios, puede ser interpretado como un tipo de brujería, o "encantamiento cinemático", que provoca la resistencia de la comunidad local.

\section{INDEX}

Palabras claves: película de ficción, colaboración, Chile, brujería y hechicería

Mots-clés: film de fiction, collaboration, Chili, sorcellerie et magie

Keywords: fiction film, collaboration, Chile, witchcraft and sorcery

\section{AUTHOR}

\section{CHRISTOPHER MURRAY}

ccmurray@gmail.com

Born in Santiago de Chile, in 1985, Christopher Murray holds a degree in filmmaking from the Universidad Católica de Chile and a Master's degree in Visual Anthropology from the University of Manchester. He directed the feature film Manuel de Ribera, the collective documentary Propaganda and is co-founder of the web documentary project MAFI - Filmic Map of a Country (www.mafi.tv). His most recent feature film, The Blind Christ, premiered in the Official Competition at the Venice Film Festival 2016. He works as a lecturer at the Universidad Católica de Chile. His academic interest focuses on the "practice as research" approach to the interface between art and anthropology. 